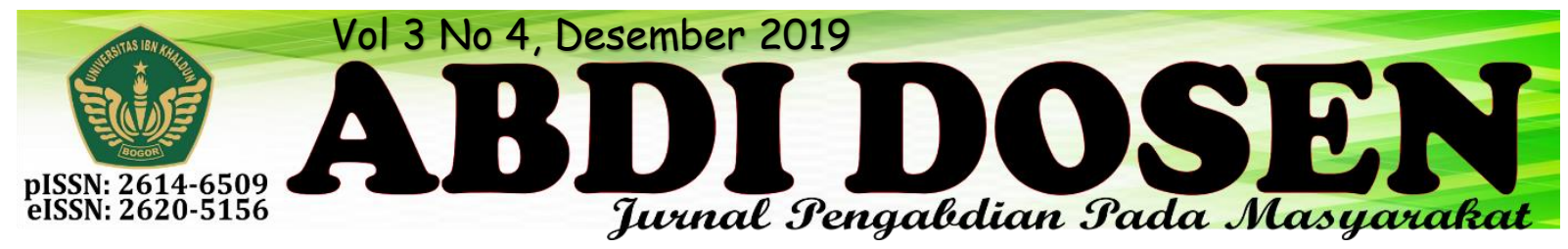

\title{
PEMBERDAYAAN MASYARAKAT DESA MELALUI METODE KERJASAMA DENGAN AKADEMISI PROGRAM KULIAH KERJA NYATA
}

\author{
Hurriyaturrohman ${ }^{1}$, Safaruddin Hidayat Al Ikhsan ${ }^{2}$, Muhamad Irfan, Miptahul Janah ${ }^{3}$ \\ hurriyaturrohman@uika-bogor.ac.id ${ }^{1}$ \\ safaruddin@ ft.uika-bogor.ac.id $^{2}$
}

Fakultas Ekonomi dan Bisnis Universitas Ibn Khaldun ${ }^{1}$, Fakultas Teknik Universitas Ibn Khaldun ${ }^{2}$, Mahasiswa KKN Kelompok 45\&46 Tahun $2018^{3}$

\begin{abstract}
ABSTRAK
Kuliah Kerja Nyata Tematik Terintegrasi merupakan salah satu program pengabdian mahasiswa yang memiliki tujuan untuk mengembangkan, meningkatkan mutu sumber daya dan mencapai efektivitas program pembangunan yang ditandai dengan semakin baiknya kualitas kehidupan masyarakat pada bidang agama islam, pendidikan, kesehatan, ekonomi, hukum dan teknologi. Kegiatan KKN dibagi menjadi beberapa tahap, yaitu survey dan observasi ke desa sasaran, workshop, pendekatan sasaran program, realisasi program, monitoring dan evaluasi kegiatan, dan lokakarya hasil KKN. Kegiatan ini dilaksanakan mulai tanggal 06 Agustus - 05 September 2019. Desa Warga Jaya merupakan salah satu desa Di Wilayah Kecamatan Cigudeg Kabupaten Bogor yang menjadi desa sasaran KKN dengan luas wilayah 772, 38 Ha yang terbagi dalam 6 Dusun, 13 RW dan 43 RT. Adapun beberapa program KKN yang dilaksanakan meliputi Taman Belajar (Tabel), Mengajar di PAUD, Mengajar di SDN, Penyuluhan Ekonomi, Re-branding product, Penyuluhan Kesehatan Sikat gigi dan Cuci tangan, Jum'at bersih, Peringatan Hari Kemerdekaan RI, Seminar Hukum, Seminar Teknologi, Pembuatan dan pemasangan plang jalan, Pembuatan dan pemasangan plakat RT, Pembuatan bak sampah dan Pembuatan Penerangan jalan. Secara umum, hasil kegiatan telah sesuai dengan rencana yang telah ditetapkan, walaupun ada beberapa hambatan yang dialami.
\end{abstract}

Kata Kunci: KKN Tematik Terintegrasi, Program KKN, Warga Jaya.

\section{PENDAHULUAN}

\section{Analisis Situasi}

Berdasarkan hasil observasi dan analisis yang kelompok kami lakukan di Desa Warga Jaya Kecamatan Cigudeg Kabupaten Bogor - Jawa Barat, Desa Warga Jaya memiliki luas wilayah 772, 38 Ha. Dengan batas wilayah sebagai berikut : Sebelah Utara: Desa Cintamanik Sebelah Selatan: Desa Cigudeg Sebelah Barat: Desa Mekarjaya
Sebelah Timur: Desa Banyuresmi

Memiliki 6 Dusun yang terdiri dari dusun Pasir Angin, Ciangger, Sabrang, Cijapuh, Cigaok, Babakan dengan Jumlah Penduduk Tahun 2019 sebanyak 6.646 Jiwa yang terdiri dari Laki-laki 3.421 Jiwa dan Perempuan 3.225 Jiwa. Jumlah Kepala Keluarga sebanyak 2.225 KK. Pekerjaan/Mata pencaharian masyarakat di Desa Warga Jaya terdiri dari Petani, 
pengusaha, pengrajin, buruh, pedagang, pengemudi/ojek dan pegawai negeri sipil

Kurangnya kesadaran akan ilmu pengetahuan, kurangnya kemauan untuk bekerja serta cukup rendah nya tingkat kesejahteraan masyarakat menjadi penyebab timbulnya beberapa masalah dengan beberapa bidang di Desa Warga Jaya, diantaranya bidang ekonomi, kesehatan, lingkungan dan pendidikan.

\section{Permasalahan yang dihadapi}

Ada beberapa permasalahan yang terdapat di Desa Warga Jaya, diantaranya :

1. Kurangnya kesadaran masyarakat akan pentingnya kebersihan sehingga sampah tidak di buang di tempat yang seharusnya dan selokan air yang sering tersumbat akibat limbah-limbah rumah tangga

2. Kurangnya sarana dan prasarana pendidikan di Desa Warga Jaya dalam membantu pembelajaran siswa

3. Kurangnya air bersih untuk mendukung keperluan masyarakat sehari - hari.

4. Akses transportasi yang kurang memadai sehingga menghambat lalu lintas warga ataupun orang pendatang.

5. Masih kurangnya tenaga pengajar yang memadai sehingga siswa kurang memperoleh pengetahuan baru dari guru.

6. Kurangnya lapangan pekerjaan yang memadai sehingga pendapatan masyarakat sangat minim

7. Kurangnya lahan untuk tempat pembuangan sampah dan masyarakat belum bisa membedakan sampah organik dan anorganik.

\section{Solusi Yang di Tawarkan}

Setelah memahami beberapa permasalahan yang terjadi di Desa Warga Jaya, maka kami menawarkan beberapa solusi, solusisolusi tersebut diantaranya :
1. Membantu mengajar di SDN Ciangger 03 khususnya pada mata pelajaran Pendidikan Agama Islam (PAI) dan Bahasa Inggris dengan berbagai metode pembelajaran.

2. Mengajar di PAUD Tarbiatul Aulad dengan tujuan untuk membantu para guru dalam mengajar agar dapat membentuk anak Indonesia yang berkualitas serta anak lebih aktif dan kreatif dalam pembelajaran.

3. Diadakannya Taman Belajar untuk membantu anak - anak sekitar dalam menyelesaikan pekerjaan rumah dari sekolah dan memberikan pengetahuan tambahan berupa bimbingan belajar.

4. Mengadakan Seminar Hukum yang bertujuan untuk memberi pemahaman hukum kepada warga desa sekecamatan Cigudeg.

5. Diadakannya penyuluhan kesehatan gigi dan mulut di PAUD Tarbiatul Aulad agar anak-anak mengetahui tentang pentingnya kesehatan gigi dan mulut

6. Mengadakan penyuluhan kesehatan cuci tangan yang baik dan benar di SD agar anak-anak terbiasa dengan gaya hidup bersih dan sehat terutama cara mencuci tangan yang baik dan benar.

7. Mengadakan Penyuluhan Ekonomi tentang Pengelolaan Keuangan Dalam Rumah Tangga untuk para ibu rumah tangga di Dusun Babakan.

8. Melakukan re-branding product dalam promosi guna memperluas dan mempermudah pemasaran produk kedepannya dengan membuat stiker, kartu nama dan banner yang sesuai dengan keinginan pemilik usaha.

9. Mengadakan seminar teknologi di SMP Islam Baitul Ilmi untuk mengenalkan bagaimana cara pemanfaatan teknologi dengan baik 
dan mengurangi kasus penyalahgunaan teknologi

10. Membuat Plang jalan dan plakat RT untuk memudahkan masyarakat mengetahui letak Dusun - dusun di suatu daerah serta agar mempermudah para pendatang untuk meminta perijinan dalam suatu kegiatan kepada Ketua RT.

11. Membuat penerangan jalan untuk dimalam hari sehingga mempermudah masyarakat dan dapat melihat dengan lebih jelas jalan/medan yang akan

\section{METODE}

Metode penelitian adalah cara utama yang digunakan dalam proses pengumpulan dan analisis data yang dilakukan secara sistematis dan logis untuk mencapai tujuan tertentu. Metode yang dilakukan dalam pelaksanaan rangkaian program KKN Tematik 2018 oleh kelompok 30 yaitu dengan cara wawancara terhadap tokoh masyarakat dan pegawai kantor desa di Desa Wargajaya. Wawancara adalah cara menghimpun bahan - bahan keterangan yang dilaksanakan dengan tanya jawab secara

\section{REALISASI PROGRAM}

Realisasi Program Mahasiswa KKN dilaksanakan selama kurang lebih 30 hari terhitung sejak tanggal 7 Agustus 2019 sampai dengan 4 September 2019. Berikut ini adalah laporan berbagai kegiatan yang telah dilaksanakan oleh mahasiswa KKN di Desa Warga Jaya, Kecamatan Cigudeg, Kabupaten Bogor yang dilaksanakan oleh enam bidang yaitu: Bidang Pendidikan, Bidang Kesehatan Masyarakat, Bidang Ekonomi, Bidang Agama, Bidang Hukum, dilalui pada malam hari di Dusun Babakan RT.01 RW.12.

12. Membuat bak sampah di Dusun Babakan RT.01 RW.12.

13. Adanya program pelaksanaan HUT RI ke 73 di Dusun Babakan Desa Warga Jaya.

14. Adanya program Jum'at bersih yang ditujukan untuk masjid sekitar ketika akan dipergunakan untuk shalat Jum'at

15. Adanya pendistribusian daging kurban untuk 18 rumah dan $35 \mathrm{KK}$ di Kampung Cikanas.

lisan, sepihak, berhadapan muka dan dengan arah tujuan yang telah ditentukan. Peneliti juga melakukan observasi langsung kepada masyarakat sebagai suatu kegiatan membandingkan fakta dan budaya yang ada dilingkungan setempat. Peneliti juga melakukan pendekatan religius terhadap masyarakat melalui bergabung ke dalam majlis ta'lim ibuibu maupun bapakbapak dusun Babakan. Peneliti juga melakukan sosialisasi dan penyuluhan kepada masyarakat sesuai program yang sudah di rencanakan.

dan Bidang Teknik dengan total 18 program kerja terlaksana.

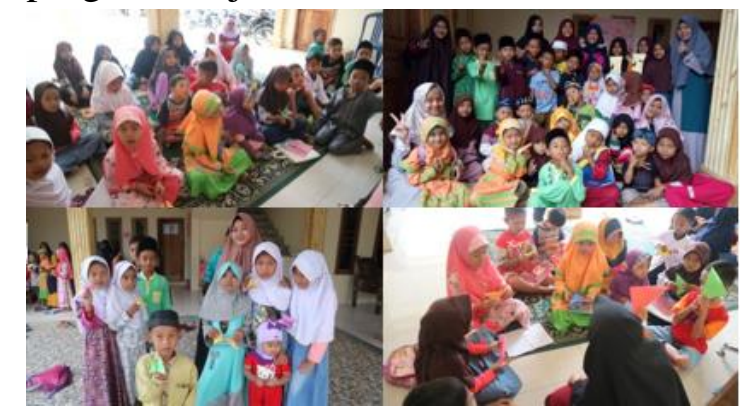

1. Taman Belajar

Taman belajar merupakan program kerja berbentuk bimbingan belajar yang 
terdiri dari 6 mata pelajaran yaitu, Matematika, Bahasa Inggris, Fiqih, Bahasa Arab, Keterampilan dan Ubudiyah. Dilaksanakan secara rutin setiap 3 hari dalam seminggu di hari Senin pukul 13.00 - 14.30, Rabu pukul 16.00 - 17.00, dan Sabtu pukul $16.00-17.00$. Tempat kegiatan ini di halaman depan posko kelompok 46 dengan Peserta anak usia PAUD s.d SMP di Desa Wargajaya khususnya Dusun Babakan. Tujuan diadakannya program kerja Taman Belajar adalah untuk membantu anak-anak di kawasan dusun Babakan Desa Wargajaya dalam meningkatkan sisi kognitif, afektif dan psikomorik serta dapat meningkatkan wawasan dan potensi yang ada pada diri mereka.

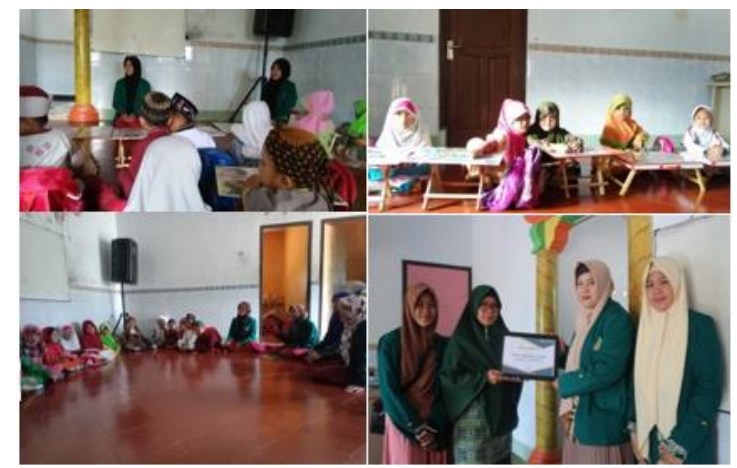

\section{Mengajar Paud}

Mengajar PAUD di PAUD Tarbiatul

Aulad, tepatnya di Dusun Babakan Desa Wargajaya selama 5 kali dengan jadwal setiap hari Senin dan Selasa pukul 08.00 10.00 WIB. Tujuan diadakannya mengajar PAUD adalah untuk membantu dewan guru yang memang kekurangan tenaga dalam mengajar untuk membentuk anak Indonesia yang berkualitas, yaitu anak yang tumbuh dan berkembang sesuai dengan tingkat perkembangannya sehingga memiliki kesiapan yang optimal di dalam memasuki pendidikan dasar serta mengarungi kehidupan pada masa dewasa.

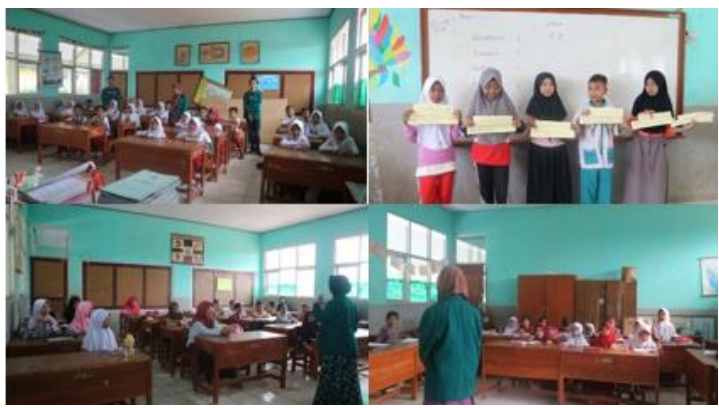

\section{Mengajar SD}

Tujuan dari program kerja ini untuk membantu proses pembelajaran di SDN Ciangger 03 khususnya pada mata pelajaran Pendidikan Agama Islam (PAI) dan Bahasa Inggris dengan berbagai metode pembelajaran. Peserta kegiatan ini adalah : Siswa kelas 3, 5 dan 6 dengan jadwal mengajar pada hari Selasa, Rabu dan Jum'at.

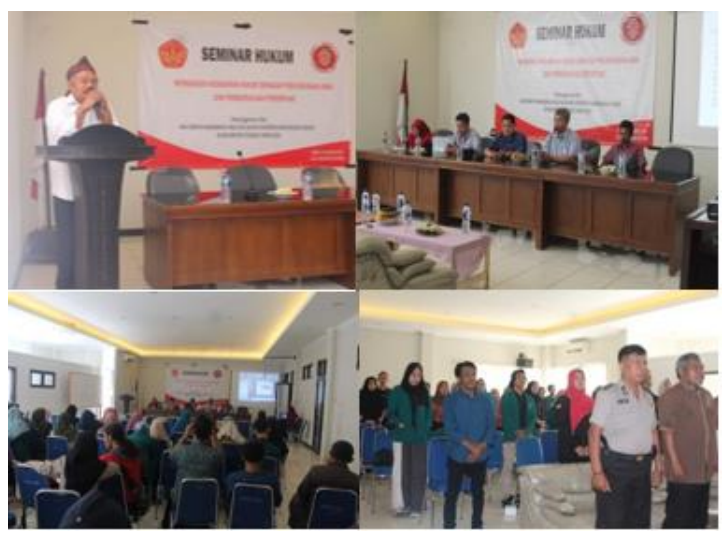

4. Seminar Hukum

Kegiatan ini dilaksanakan di Aula Kecamatan Cigudeg pada hari Sabtu, 24 Agustus 2019 pukul 10.00 - 12.00 di hadiri oleh 69 peserta dari kalangan ibu-ibu PKK, tokoh masyarakat, Polsek Cigudeg, KNPI dan mahasiswa yang sedang KKN di Kecamatan Cigudeg. Kegiatan ini bertemakan "Membangun Kesadaran Hukum Terhadap Perlindungan Anak dan Pemberdayaan Perempuan “. Kegiatan ini bertujuan untuk memberi pemahaman hukum kepada warga desa sekecamatan Cigudeg terhadap anak dan perempuan serta membuka pikiran masyarakat untuk memahami soal aspek hukum. 


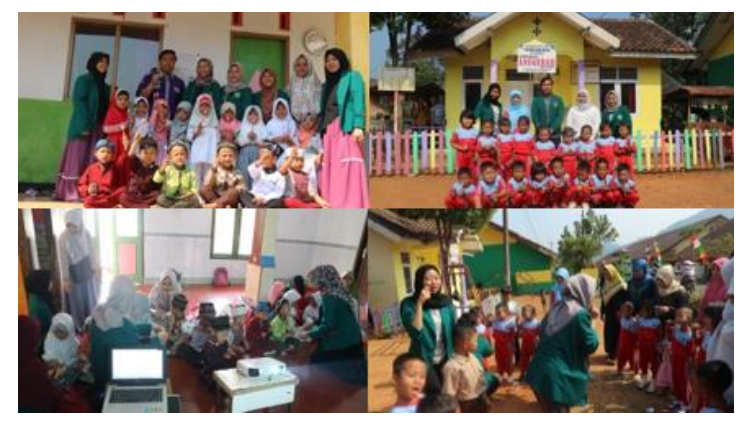

5. Penyuluhan kesehatan gigi dan mulut

Penyuluhan kesehatan gigi dan mulut diadakan di lapangan PAUD Tarbiatul Aulad pada hari Senin, 19 Agustus 2019 dan di lapangan PAUD Anugerah pada hari Kamis , 23 Agustus 2019. Tujuan dari program ini adalah mengubah perilaku kearah yang lebih sehat sehingga tercapai derajat kesehatan gigi dan mulut masyarakat yang optimal, menambah pengetahuan anak-anak tentang pentingnya kesehatan gigi dan mulut, mengurangi faktor penyakit gigi berlubang, dan anakanak lebih mengerti manfaat menyikat gigi yang baik dan benar.

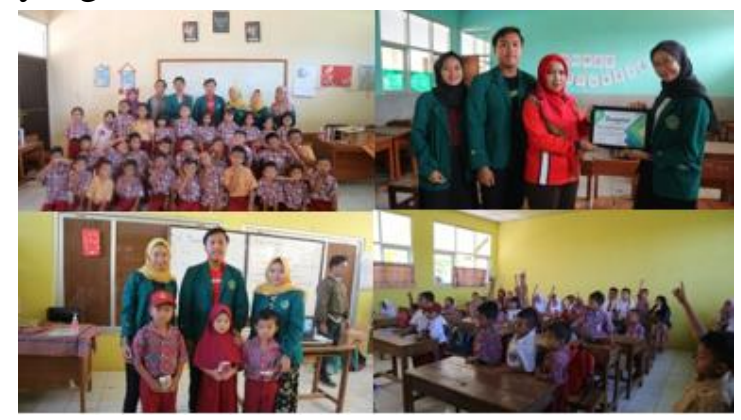

\section{Penyuluhan kesehatan 6 langkah cuci tangan yang baik dan benar}

Penyuluhan kesehatan 6 langkah cuci tangan yang baik dan benar diadakan di Ruangan Kelas SDN Ciangger 01, SDN Ciangger 02, SDN Ciangger 03 pada hari Selasa, 20 Agustus 2019 dan Rabu, 21 Agustus 2019 dengan peserta anak-anak SD kelas 1-3. Tujuan dari program ini adalah untuk menghilangkan kotoran dan debu secara mekanis dari permukaan kulit dan mengurangi jumlah mikroorganisme, serta agar anak-anak terbiasa dengan gaya hidup bersih dan sehat terutama cara mencuci tangan yang baik dan benar baik itu di sekolah maupun di rumah.

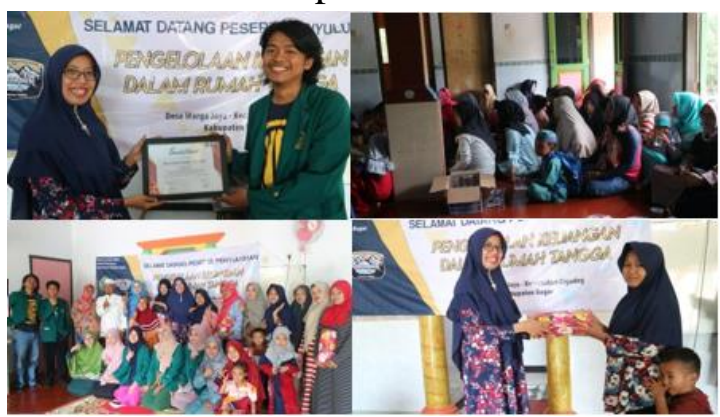

\section{Penyuluhan Ekonomi}

Penyuluhan Ekonomi dengan tema "Pengelolaan Keuangan dalam Rumah Tangga" adalah sebuah program kerja yang dilaksanakan oleh Fakultas Ekonomi bekerjasama dengan Program Studi Ekonomi Syari'ah untuk memberikan arahan serta pemaparan terkait bagaimana cara mengelola keuangan dalam rumah tangga yang baik dan benar. Dengan diadakannya penyuluhan ini diharapkan masyarakat, khususnya para ibu rumah tangga di dusun Babakan mampu menganalisis pengeluarannya serta dapat memahami antara kebutuhan primer dan kebutuhan sekunder. Kegiatan ini dilaksanakan pada hari Selasa, 20 Agustus 2019 pukul 10.30 - 12.00 WIB bertempat di Pondok Pesantren Tarbiatul Aulad, Dusun Babakan, Desa Wargajaya, Kecamatan Cigudeg, Kabupaten Bogor dengan pemateri Ibu Hurriyaturrohman, SE., MM. Peserta dari penyuluhan ini berjumlah 38 orang.

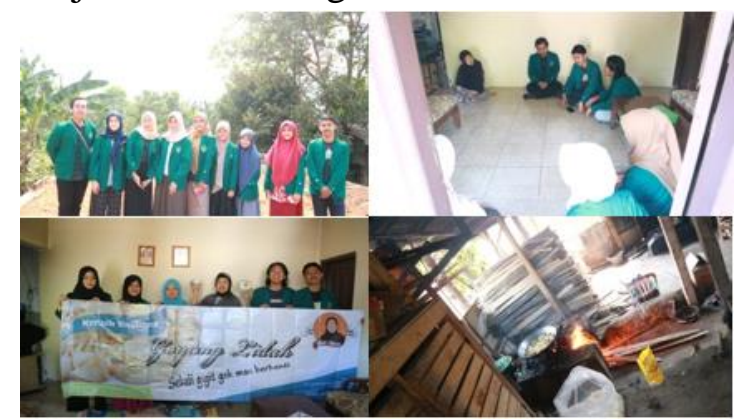

8. Re-branding product 
Re-branding merupakan suatu upaya atau usaha yang dilakukan untuk merubah atau memperbaharui sebuah brand yang telah ada agar menjadi lebih baik, dengan tidak mengabaikan tujuan awal suatu usaha atau perusahaan. Sasaran dari program kerja ini adalah mere-branding product keripik singkong Ibu Ikah yang telah didirikan dan berjalan sejak lama dengan proses yang manual menggunakan tungku dan di potong menggunakan pemotong yang di desain sendiri menggunakan bahan yang sederhana seperti kayu dan kater. Dalam re-branding yang kami lakukan memfokuskan dalam segi promosi guna memperluas dan mempermudah pemasaran produk kedepannya dengan membuat stiker, kartu nama dan banner yang sesuai dengan keinginan pemilik usaha dengan diadakannya konsultasi secara berkala agar desain dan kelengkapannya sesuai keinginan seperti nama brand, alamat lengkap, slogan, dan lain sebagainya. Kami mendatangi pabrik keripik singkong Ibu Ikah sebanyak 3 kali, yaitu pada hari Rabu 14 Agustus 2019, Kamis 22 Agustus 2019 dan Jum'at 30 Agustus 2019.

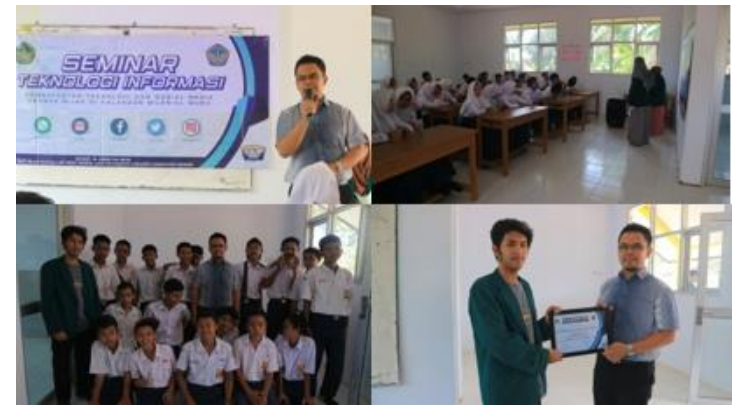

\section{Seminar teknologi}

Program kerja yang dibentuk dengan cara mengadakan Seminar Teknologi dengan judul "Pemanfaatan Teknologi dan Media Sosial Secara Bijak Di Kalangan Milenial Muda”. Program ini dilaksanakan pada hari Senin, 2 September 2019 pukul 10.00 - 12.00 WIB dengan pemateri Bapak Safaruddin Hidayat Al Ikhsan, M. Kom.
Program kerja ini dibentuk agar mengenalkan bagaimana cara pemanfaatan teknologi dengan baik, mengurangi kasus penyalahgunaan teknologi serta meningkatkan wawasan teknologi kepada para siswa-siswi kelas 9 di SMP Islam Baitul Ilmi yang berjumlah 36 orang. Kegiatan ini merupakan kegiatan yang sangat dibutuhkan oleh kalangan muda khusus nya di smp baitul hilmi dikarenakan kondisi disana belum ada arahan mengenai, bagaimana cara menggunakan teknologi dengan baik dan bijak.

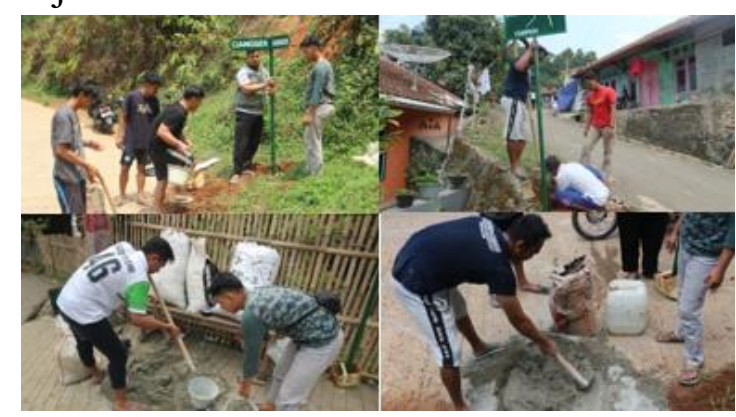

10. Membuat Plang jalan dan plakat RT

Tujuan pembuatan plang jalan ini adalah untuk memudahkan masyarakat sekitar khususnya masyarakat awam dalam mengetahui letak Dusun - dusun di suatu daerah. Sedangkan pembuatan plakat papan RT setempat agar mempermudah para pendatang untuk meminta perijinan dalam suatu kegiatan di Desa Warga Jaya. Kecamatan Cigudeg, Kabupaten Bogor. Bahan yang digunakan untuk membuat plang jalan adalah bahan plat besi dengan ketebalan $2 \mathrm{~mm}$, pipa besi berdiameter $10 \mathrm{~cm}$ sebagai penyangga dan di sertakan adukan semen pada pemasangan agar tiang penyangga lebih kuat dan kokoh. Kami membuat satu plang arah jalan, satu buah plang jalan (peta), tiga buah plakat papan RT yang menunjukkan letak arah dusun, peta arah jalan dan Gang serta kediaman ketua RT 
setempat. Kegiatan ini dilakukan pada hari Ahad, 01 September 2019.

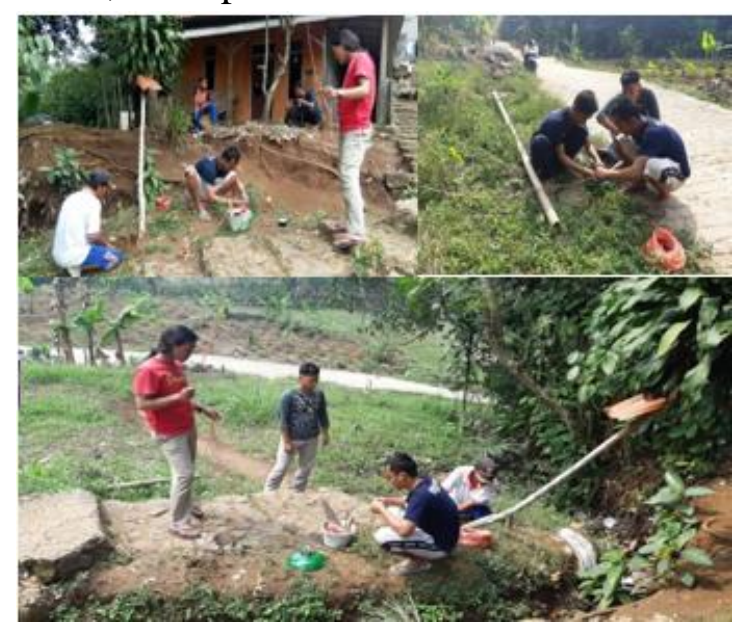

\section{Membuat penerangan jalan}

Lampu jalan atau dikenal juga sebagai penerangan jalan umum ( PJU ) adalah lampu yang digunakan untuk penerangan jalan dimalam hari sehingga mempermudah pejalan kaki, pesepeda, dan pengendara kendaraan dapat melihat dengan lebih jelas jalan/medan yang akan dilalui pada malam hari, sehingga dapat meningkatkan keselamatan lalu lintas dan keamanan para pengguna jalan dari kegiatan atau aksi kriminal. Penerangan jalan yaitu tindakan yang baik untuk program kerja KKN di Desa Warga Jaya Kec. Cigudeg, dikarenakan akan menghalangi tindakan kejahatan yang mengambil manfaat serta keuntungan dari kegelapan malam. Program kerja ini dilaksanakan pada hari Senin, 02 September 2019, Pukul, 13:47 WIB, di Dusun Babakan RT.001 RW.12.
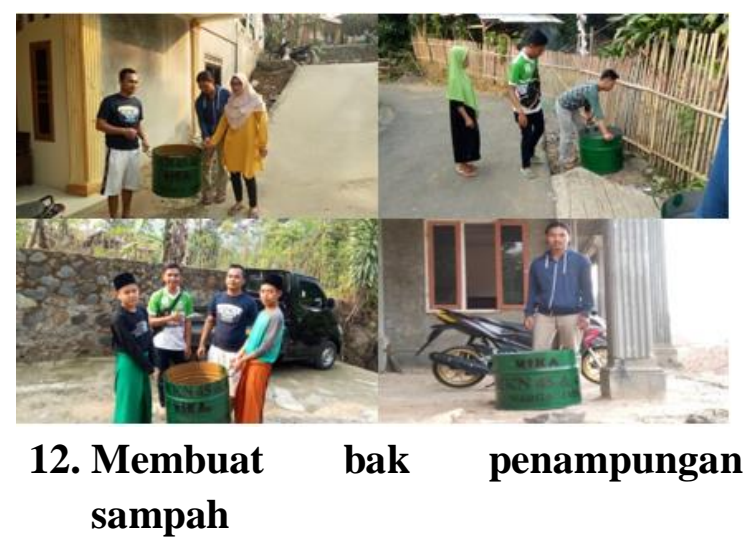

Bak penampungan sampah merupakan wadah untuk menampung sampah-sampah plastik, organik dan non organik yang terbuat dari pemanfaatan kembali drum bekas yang sudah tidak terpakai, yang dibelah $1 / 2$ dari ukuran drum utuh, kemudian di lapisi cat guna menghindari dari karat, korosi dan untuk memperindah tampilan dari bak tersebut. Bak penampungan sampah juga dapat di kembangkan dan dikelola oleh warga sekitar, dengan cara mengumpulkan dan memisahkan beberapa jenis sampah terutama sampah plastik untuk di manfaatkan kembali menjadi kerajinan tangan dan lain-lain. Program ini dilaksanakan pada hari Sabtu, 31 Agustus 2019, Pukul, 08:00 WIB di Dusun Babakan RT.001 RW.12.

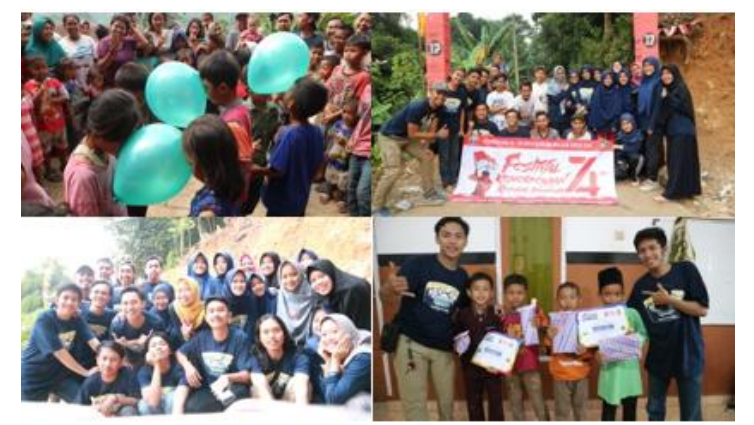

\section{Pelaksanaan HUT RI ke 73}

Peringatan Hari Kemerdekaan RI adalah salah satu program kerja kami yang bekerjasama dengan pemuda Karang Taruna Dusun Babakan, Desa Warga Jaya. Peringatan Hari Kemerdekaan RI ini juga dilaksanakan di Dusun Sabrang dan Dusun Cijapuh pada hari yang sama. Kegiatan ini dilaksanakan pada hari Sabtu, 17 Agustus 2019 pukul 09.00 - 16.00 WIB di halaman rumah Ustadz Ajun di Dusun Babakan. Dalam peringatan Hari Kemerdekaan RI ini diadakan lomba - lomba untuk anak anak seumuran PAUD sampai dengan kelas 6 SD dan ibu - ibu Dusun Babakan seperti lomba makan kerupuk, lomba balap karung memakai helm, lomba balap 
kelereng, lomba memasukkan paku ke botol, lomba joget balon dan lomba mewarnai. Tujuan dari program ini adalah untuk menjalin rasa gotong royong dan kebersamaan terhadap sesama masyarakat, membangkitkan rasa patriotisme atau jiwa perjuangan, meramaikan hari kemerdekaan RI, serta menjalin silaturahmi antara mahasiswa dan masyarakat.

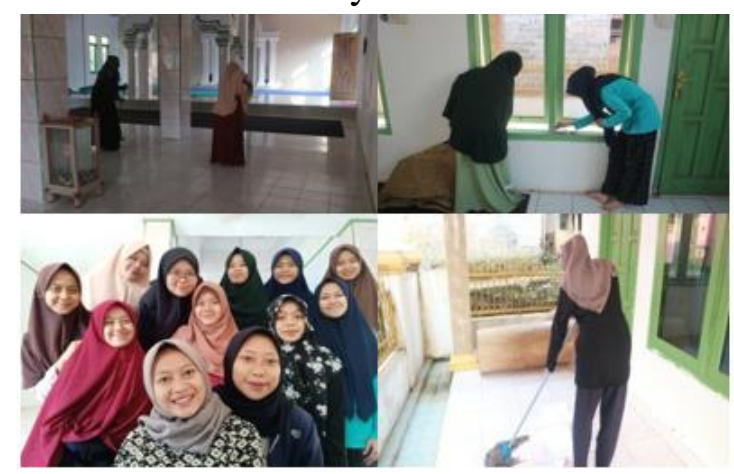

\section{Jum'at bersih}

Jum'at bersih adalah kegiatan membersihkan masjid di pagi hari, dimana masjid tersebut dipergunakan untuk shalat Jum'at oleh kaum laki - laki. Kegiatan ini dilakukan 1 minggu sekali di hari Jum'at pukul 06.30 - 07.30. Tujuan dari program ini adalah agar masyarakat yang hendak shalat Jum'at merasa nyaman dan khusyu' karena masjid yang mereka datangi bersih dan wangi mulai dari karpet, lantai, kaca, kamar mandi maupun halaman masjid.

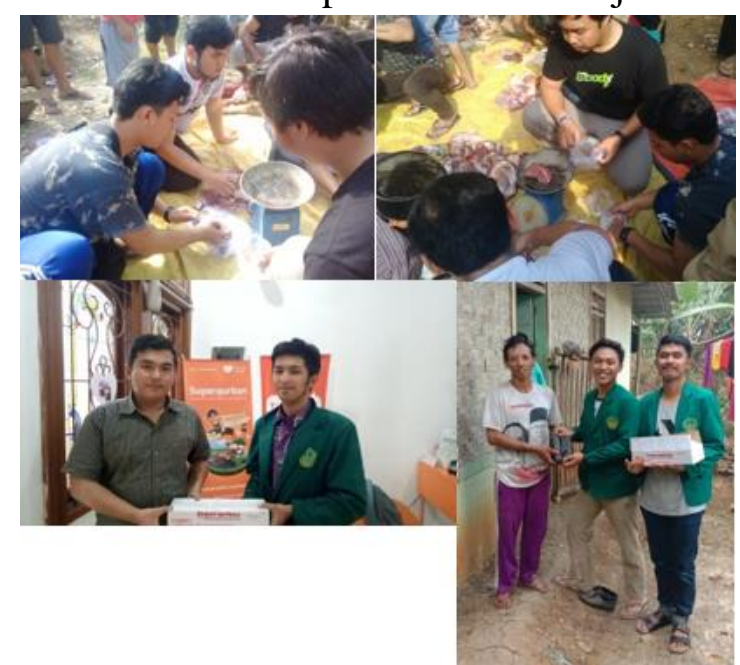

\section{Pemotongan Hewan Qurban dan Pendistribusian daging kurban}

Pada hari raya Idul Adha di hari Ahad 11 Agustus 2019 kami membantu proses pemotongan hewan qurban di Dusun Babakan dan membantu untuk mendistribusikannya kepada warga sekitar. Sedangkan pada hari Selasa, 13 Agustus 2019 kami melakukan pendistribusian daging kurban kepada warga Kampung Cikanas. Tujuan dari pendistribusian daging kurban ini adalah agar masyarakat Kampung Cikanas dapat merasakan daging kurban, karena berdasarkan hasil survey yang kami lakukan Kampung Cikanas belum pernah mendapatkan jatah daging kurban selama Idul Adha. Pendistribusian daging kurban ini bekerjasama dengan Rumah Zakat dan mendapatkan kornet daging sapi kalengan untuk dibagikan ke 18 rumah 35 Kepala Keluarga.

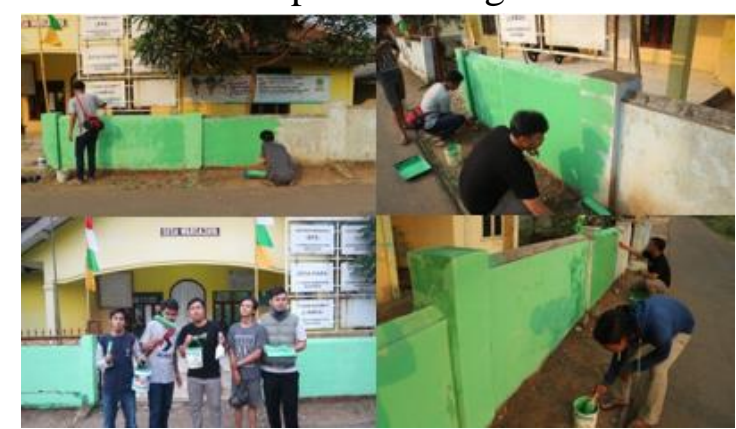

16. Pengecatan pagar tembok Kantor Desa Wargajaya

Kegiatan ini dilakukan dengan tujuan meremajakan pagar tembok Kantor Desa Wargajaya agar terlihat rapi dan indah. Kegiatan ini dilakukan di sore hari pada hari Sabtu, 31 Agustus 2019.

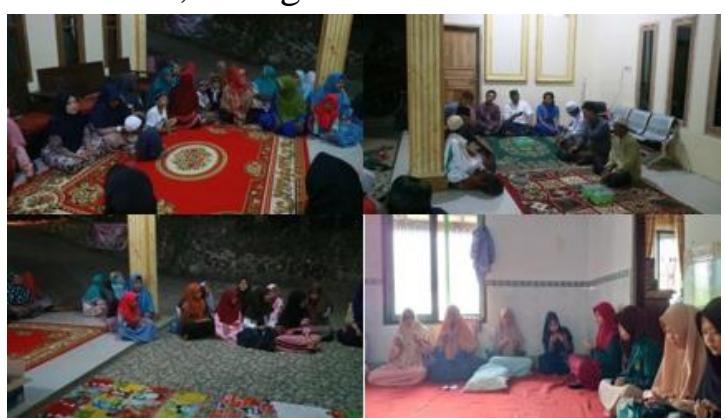

\section{Pengajian Dusun Babakan}

Program Pengajian Salawat malam Jum'at, Pengajian Bapak bapak dan 
Pengajian Ibu-ibu dilaksanakan setiap 1 minggu sekali. Pengajian ini sudah rutin dilakukan dan para mahasiswa mengikuti pengajian ini. Pengajian salawat malam Jum'at dilaksanakan setiap hari Kamis pukul 18.30 - 19.30 secara bergilir di Ponpes Tarbiatul Aulad atau di rumah Bapak Eman. Pengajian Bapak bapak dilaksanakan setiap hari Rabu pukul 18.3019.30 WIB di Masjid dan untuk pengajian ibu-ibu dilaksanakan setiap hari Rabu pukul 16.00 - 17.00 WIB di majlis Ponpes Tarbiatul Aulad. Tujuan dari program kerja ini adalah mendekatkan diri dengan masyarakat sekitar agar mudah berinteraksi dan menjaga silaturahmi dengan ibu-ibu ataupun dengan bapak bapak Dusun Babakan.

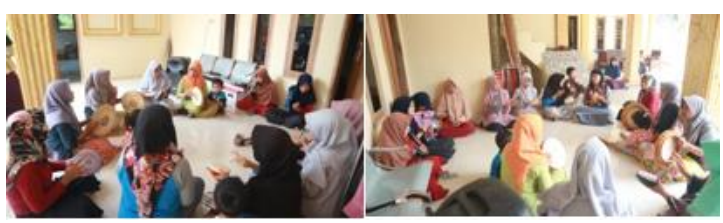

18. Qasidah ibu - ibu

Kegiatan ini dilaksanakan pada hari Kamis pukul 13.00 - 15.00 WIB di rumah Bu Zubaidah di Dusun Babakan. Kegiatan Qasidah ini diikuti oleh kurang lebih 10 orang ibu - ibu masyarakat Dusun Babakan. Mahasiswa kelompok 46 juga sering mengikuti kegiatan ini bersama ibu - ibu dan mengambil peran untuk memegang alat musik qasidah tersebut. Tujuan dari program ini adalah untuk menjalin silaturahmi dengan ibu - ibu dan mengenal kesenian Islam. 


\section{KESIMPULAN}

KKN Tematik Terintegrasi

Universitas Ibn Khaldun Bogor menempatkan mahasiswa di luar kampus agar mahasiswa hidup ditengah-tengah masyarakat, bersama masyarakat untuk membantu dan mendampingi masyarakat memanfaatkan potensi sumber daya alam local dan sumber daya manusia yang ada untuk mengatasi permasalahan masyarakat dalam kurun waktu tertentu. Sesuai dengan tujuan dari kegiatan KKN Tematik Terintegrasi Universitas Ibn Khaldun Bogor, Kelompok KKN 45 dan 46 mengadakan program kerja dalam bidang pendidikan, agama, kesehatan, ekonomi,

\section{REFERENSI}

Administrasi profil desa

Efendi, M. (2009). Using Collaborative Technique to improve the ability of students at MTSN PULOSARI TULUNGAGUNG IN Writing Descriptive Text. Malang: University press. teknik dan hukum. Namun, Keberhasilan KKN tidak lepas dari kerja sama antara mahasiswa dengan perangkat desa, masyarakat, serta semua pihak yang membantu dan mendukung terlaksananya kegiatan KKN. Dengan adanya mahasiswa KKN masyarakat terbantu dengan bertambahnya informasi dan ilmu pengetahuan yang mereka peroleh dari mahasiswa KKN. Tetapi, Kurangnya kepedulian, kepekaan dan antusiasme masyarakat desa terhadap kegiatan $\mathrm{KKN}$ sempat menjadi hambatan. Namun secara garis besar program KKN kelompok 45 dan 46 dapat dikatakan sukses dan lancar. (2018). Petunjuk Pelaksanaan KKN Tematik Terintegrasi 2018 Universitas Ibn Khaldun Bogor. Bogor : UIKA Press.

http://pkm.uikabogor.ac.id/index.php/ABDIDOS/iss ue/archive 